\title{
An investigation of lemma micromorphology in Thai Oryzeae (Poaceae)
}

\author{
Pirada Sumanon, Paweena Traiperm* \\ Department of Plant Science, Faculty of Science, Mahidol University, Bangkok 10400 Thailand \\ *Corresponding author, e-mail: paweena.tra@mahidol.ac.th
}

Received 23 Apr 2013

Accepted 28 Oct 2013

\begin{abstract}
Nine taxa of Oryzeae that occur naturally in Thailand were studied for their lemma micromorphology using scanning electron microscopy. Common features found in most taxa were microhairs, prickles, silica bodies, and papillae. Here, features of the lemma surface are described, classified, and discussed in terms of their taxonomic significance. In addition, a key to species based on the shape of silica bodies, type of papillae and tubercles, and the arrangement of tubercles is presented. However, lemma micromorphology alone cannot be used to distinguish three species in the Oryza sativa group, namely, $O$. sativa, $O$. rufipogon, and $O$. officinalis.
\end{abstract}

KEYWORDS: Oryza, Leersia, Hygroryza, Zizania

\section{INTRODUCTION}

Oryzeae Dumort. is a tribe in the grass family (Poaceae) consisting of twelve genera and around seventy species distributed in tropical and warm temperate regions of the world ${ }^{1}$. Notably, the tribe contains cultivated rice (Oryza sativa L.) and its relatives, making it an attractive group for systematic studies. Accordingly, various investigations into the morphology ${ }^{2}$, anatomy ${ }^{3}$, cytology ${ }^{4}$, and molecular phylogenetics ${ }^{5-7}$ of the tribe have been published. The consensus of these and other studies is that tribe Oryzeae belongs in subfamily Ehrhartoideae, one of three subfamilies of the BEP (Bambusoideae, Ehrhartoideae, and Pooideae) clade ${ }^{8,9}$.

In Thailand, four genera of Oryzeae are found ${ }^{10}$ : Oryza L., Leersia Sw., Hygroryza Nees, and Zizania L. The genus Oryza contains five species and two varieties, while Hygroryza is a monotypic genus containing only $H$. aristata Nees. The genus Leersia contains $L$. hexandra Sw., a common weed of rice fields, and $L$. stipitata Bor, which has been recorded only in Chanthaburi province in 1961. Whereas these nine taxa are native to Thailand, Z. latifolia Turcz. ex Stapf, also known as wild rice, was introduced to Thailand for cultivation.

In general, taxonomic classification of grasses has relied on spikelet structure and the number of florets, as well as lemma and palea characters. However, the use of this classification has some limitations because of similarity in morphology. Barthlott ${ }^{11}$ emphasised the value of epidermal and seed surface characters in a systematic analysis for classification at both the specific and familial levels, since these characters are little affected by the growing environment. Scanning electron microscope (SEM) observations of achene morphology in Polygonum s.l. ${ }^{12}$ and of fruit and seed structure in Scrophulariaceae ${ }^{13}$ have underscored the systematic importance of these characters in a taxonomic context.

Numerous studies have investigated micromorphology in various groups within the Poaceae, and overall these have helped establish the usefulness of this field of study in the family. For example, SEM was used to investigate surface characters of both vegetative and reproductive parts of the subfamily Danthonioideae ${ }^{14}$, and to identify five lemma micromorphological characters (namely, long cells, cork cells, stomata, papillae, and microprickles) that optimize a molecular cladogram of Chloridoideae grasses ${ }^{15}$. Hence micromorphology of lemma surfaces is expected to aid taxonomic classification of grasses.

In tribe Oryzeae, SEM has been used for many diverse applications. It was used for ultrastructural description of leaf blades, ligules, auricles and spikelets among Oryza latifolia, O. glumaepatula, and $O$. grandiglumis, wild rice species of Tropical America ${ }^{16-18}$. In addition, Hoagland and Paul ${ }^{19}$ used SEM to compare the surfaces of seeds and coleoptiles of red rice and other commercial varieties, while Thammawongsa et $\mathrm{al}^{20}$ found that the lemma surface is a taxonomically valuable source of information when used in combination with other morphological 
Table 1 List of voucher specimens of Thai Oryzeae used in this study. Herbarium acronyms are given in parentheses.

\begin{tabular}{|c|c|}
\hline Taxon & Voucher specimen \\
\hline Hygroryza aristata Nees & $\begin{array}{l}\text { Thailand: Bangkok, A.F.G. Kerr } 3883 \text { (BK) } \\
\text { Thailand: Songkhla, A.F.G. Kerr } 15119 \text { (BK) }\end{array}$ \\
\hline Leersia hexandra Sw. & $\begin{array}{l}\text { Thailand: Kamphaeng Phet, P. Sumanon \& P. Traiperm } 5 \text { (BKF) } \\
\text { Thailand: Khon Kaen, C. Jaroenchai } 31 \text { (KKU) } \\
\text { Thailand: Sakon Nakhon, Piyarat \& Monthon } 1 \text { (KKU) }\end{array}$ \\
\hline $\begin{array}{l}\text { Oryza meyeriana (Zoll. \& Moritzi) } \\
\text { Baill. var. meyeriana }\end{array}$ & Thailand: Phatthalung. P. Sumanon \& P. Traiperm 1 (BKF) \\
\hline $\begin{array}{l}\text { Oryza meyeriana (Zoll. \& Moritzi) } \\
\text { Baill. var. granulata } \\
\text { (Nees \& Arn. ex G. Watt) Duist. }\end{array}$ & $\begin{array}{l}\text { Thailand: Phetchabun, P. Sumanon \& P. Traiperm } 3 \text { (BKF) } \\
\text { Thailand: Phetchabun, P. Sumanon \& P. Traiperm } 4 \text { (BKF) } \\
\text { Thailand: Chon Buri, J.F. Maxwell 75-399 (BK) } \\
\text { Thailand: Loei, C. Jaroenchai } 187 \text { (KKU) }\end{array}$ \\
\hline Oryza officinalis Wall. & $\begin{array}{l}\text { Thailand: Saraburi, J.F. Maxwell 74-595 (BK) } \\
\text { Thailand: Saraburi, C. Chermsiriwattana } 620 \text { (BK) } \\
\text { Thailand: Nonthaburi, Umpai s.n. (BK) }\end{array}$ \\
\hline Oryza ridleyi Hook. f. & $\begin{array}{l}\text { Thailand: A.F.G. Kerr } 21662 \text { (BK) } \\
\text { Thailand: Chachoengsao, A.F.G. Kerr } 19780 \text { (BK) } \\
\text { Thailand: Sa Kaeo, Put } 3103 \text { (BK) }\end{array}$ \\
\hline Oryza rufipogon Griff. & $\begin{array}{l}\text { Thailand: Kamphaeng Phet, P. Sumanon \& P. Traiperm } 6 \text { (BKF) } \\
\text { Thailand: Kamphaeng Phet, P. Sumanon \& P. Traiperm } 8 \text { (BKF) } \\
\text { Thailand: Phetchaburi, A.F.G. Kerr 11088 (BK) } \\
\text { Thailand: Chachaengsao, Yingyong P. S2-20-79 (BK) }\end{array}$ \\
\hline Oryza sativa $\mathrm{L}$. & $\begin{array}{l}\text { Thailand: Kamphaeng Phet, P. Sumanon \& P. Traiperm } 10 \text { (BKF) } \\
\text { Thailand: Chiang Mai, Yingyong Paisooksantivatana s.n. (KKU) } \\
\text { Thailand: Khon Kaen, P. Chantaranothai \& J. Parnell 90/675 (KKU) }\end{array}$ \\
\hline Zizania latifolia Turcz. ex Stapf & Thailand: Bangkok, Umpai 518A (BK) \\
\hline
\end{tabular}

and anatomical characters and were able to construct a key for the identification of 26 lowland black rice specimens.

Even though epidermal features and spikelet micromorphology in Oryza and related genera including Leersia, Zizania, Rhynchoryza, and Porteresia have been examined using SEM method in previous studies $^{21-23}$, not all taxa found in Thailand have been investigated. In particular, Hygroryza has never been studied in this way before, and no key for species-level identification based on micromorphological characters has been provided. Hence the present study sought to use SEM in a micromorphological survey of the Oryzeae of Thailand in an attempt to describe and compare lemma surface details upon which a key to the composite species could be constructed.

\section{MATERIALS AND METHODS}

\section{Plant materials}

Plant materials were collected from the field and from herbarium specimens (Table 1).

\section{SEM investigation}

The spikelets of plants were cleaned by immersion in $70 \%(\mathrm{v} / \mathrm{v})$ ethanol and sonicated for $10 \mathrm{~min}$ to remove contaminants. Then the samples were soaked in $95 \%$ ethanol, dried, and mounted on stubs using carbon tape. After that, they were coated with platinumpalladium in a sputter coater (HITACHI E-102 ION SPUTTER) and photographed using an HITACHI S2500 scanning electron microscope. The terminology used in this study mainly follows Metcalfe ${ }^{24}$, Terrell et $\mathrm{al}^{21}$, Terrell and Wergin ${ }^{23}$, and Terrell et $\mathrm{al}^{22}$.

\section{RESULTS}

Common features found on lemma surfaces of the Oryzeae species studied were microhairs, prickles, silica bodies, and papillae. For nine taxa of Oryzeae examined in this study, SEM photographs showed clear differences in lemma surfaces, as summarised below.

Hygroryza aristata (Fig. 1). Lemma and palea were 5-5.5 mm long and 1-1.25 mm wide. Prickles 

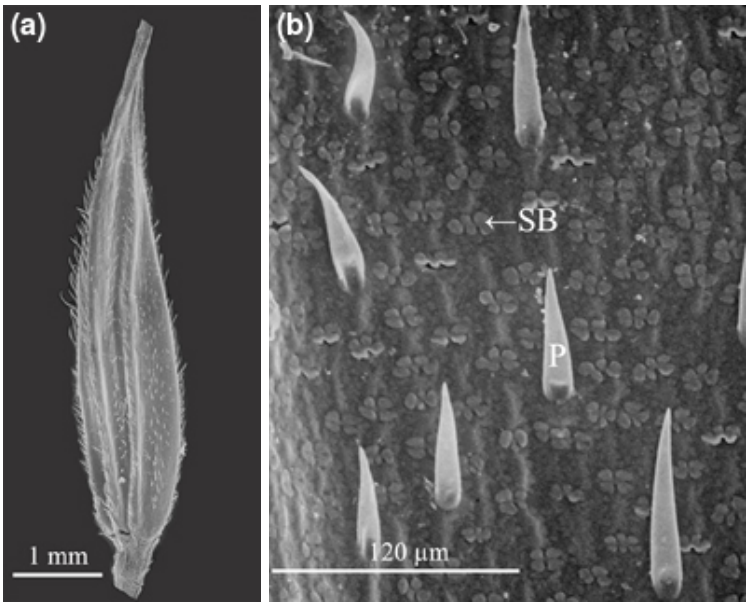

Fig. 1 SEM micrographs of the lemma of $H$. aristata, (a) whole lemma, (b) details on lemma surface $(\mathrm{P}=$ prickle; $\mathrm{SB}=$ silica body).
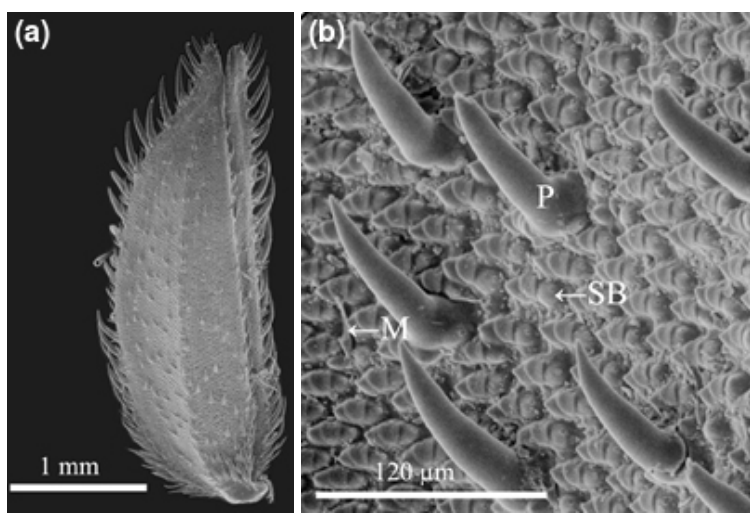

Fig. 2 SEM micrographs of the lemma of L. hexandra, (a) whole lemma, (b) details on lemma surface $(\mathrm{P}=$ prickle; $\mathrm{M}=$ microhair; $\mathrm{SB}=$ silica body).

were one-celled, pointed, 60-90 $\mu \mathrm{m}$ long, mostly arranged in rows. Silica bodies were four lobed, scattered over the lemma surface. No papillae were found.

Leersia hexandra (Fig. 2). Lemma and palea were 3-4 mm long and 1-1.2 mm wide. Microhairs were two-celled, panicoid type, with a short basal cell and a longer distal cell, 18-27 $\mu \mathrm{m}$ long, scattered, and arranged in furrows between siliceous triads. Silica bodies were triads formed of tubercles, with terminal pores, scattered over the lemma surface. Prickles were one-celled, pointed, 75-120 $\mu \mathrm{m}$ long, arranged in rows. No papillae were found.

Zizania latifolia (Fig. 3). Since this taxon produced unisexual florets, both female and male florets were examined. These two floret types differed in length, but not in lemma surface sculpturing. In female florets, lemma and palea were $1-1.2 \mathrm{~cm}$ long and $1-1.5 \mathrm{~mm}$ wide, while lemma and palea of male florets were $1.5-2 \mathrm{~cm}$ long and $1.2-1.5 \mathrm{~mm}$ wide. Pistillate and staminate lemmas were sculptured with silica bodies, papillae, pitted papillae, prickles, and microhairs. Microhairs were two-celled, panicoid type, with a short basal cell and a longer distal cell, 30-45 $\mu \mathrm{m}$ long, and arranged in rows with prickles between cells. Silica bodies were bi-lobed to orbicular, placed in furrows between cells, scattered over lemma surface. Prickles were one-celled, pointed, and variable in length from 30-120 $\mu \mathrm{m}$. Two types of papillae were found - rounded siliceous papillae and pitted siliceous papillae. Each cell contained 1 or 2 papillae.

Species belonging to the genus Oryza could be divided into three groups based on their surface sculpturing, especially with respect to tubercle characters. The first group included the two varieties of $O$. meyeriana, var. granulata and var. meyeriana, the second group consisted of $O$. sativa, $O$. rufipogon, and $O$. officinalis (the ' $O$. sativa group'), and the last group contained only one species, $O$. ridleyi.

The two varieties of $O$. meyeriana exhibited unique tubercle characters (Fig. 4). The tubercles consisted of rounded papillae and bent prickles. These large, complex tubercles were conspicuous, positioned over the furrows and distributed over the entire surface of the lemma in both varieties.

O. meyeriana var. meyeriana (Fig. 4a,b). Lemma and palea were 5-6.5 mm long and 1.5-2 $\mathrm{mm}$ wide. Microhairs were two-celled, panicoid type, very small (approx. $21 \mu \mathrm{m}$ in length) and occurred in furrows. Tubercles were 50-70 $\mu \mathrm{m}$ wide, composed of rounded papillae and one short (23-34 $\mu \mathrm{m}$ in length), sharp pointed to bent prickle at the centre of tubercles, located over the furrows, and scattered over the surface of the lemma. Numerous papillae were found over the surface of the lemma. Many papillae were on the same cell. All papillae were rounded.

O. meyeriana var. granulata (Fig. 4c,d). Lemma and palea were $4.5-5.5 \mathrm{~mm}$ long and $2.2-3 \mathrm{~mm}$ wide. Tubercles were 40-65 $\mu \mathrm{m}$ wide, composed of rounded papillae and one short (34-49 $\mu \mathrm{m}$ in length), bent prickle at the centre of tubercles, positioned over the furrows, and densely scattered over the surface of lemma. Numerous papillae, each cell had many papillae. All papillae were rounded.

O. ridleyi (Fig. 5a,b) also had tubercles over the furrows as in the $O$. meyeriana group; but, it was separated from the two varieties of that group because of its simple tubercles. Lemma and palea were 0.7- 

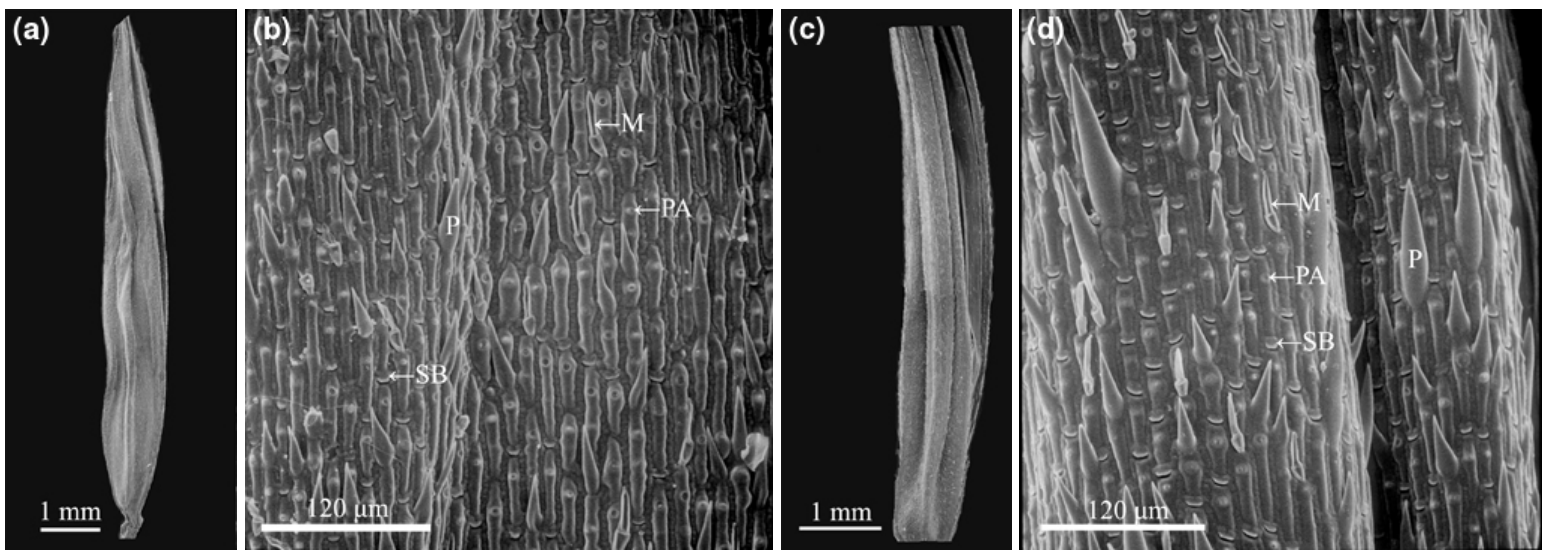

Fig. 3 SEM micrographs of the lemma of Z. latifolia, (a)-(b) female floret and (c)-(d) male floret $(\mathrm{P}=$ prickle; $\mathrm{M}=$ microhair; $\mathrm{SB}=$ silica body; $\mathrm{PA}=$ papillae).
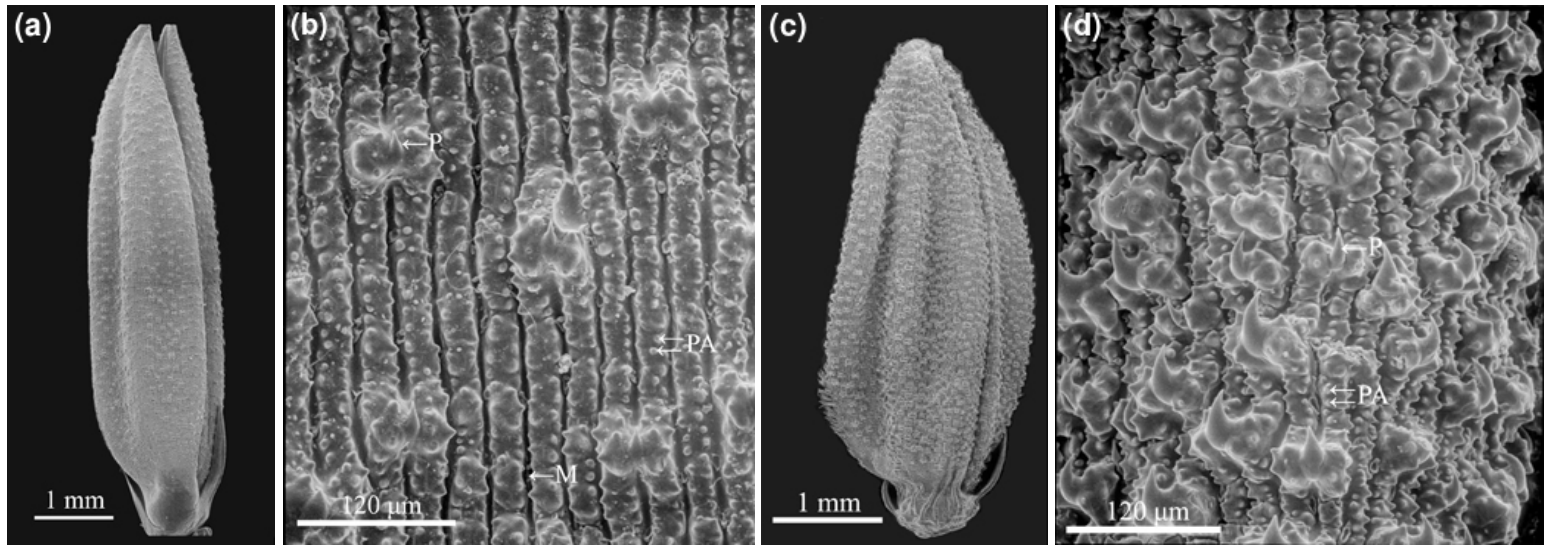

Fig. 4 SEM micrographs of the lemma of (a)-(b) O. meyeriana var. meyeriana and (c)-(d) O. meyeriana var. granulata $(\mathrm{P}=$ prickle; $\mathrm{PA}=$ papillae; $\mathrm{M}=$ microhair).

$1 \mathrm{~cm}$ long and $1.5-2 \mathrm{~mm}$ wide. Tubercles were $38-$ $47 \mu \mathrm{m}$ wide, simple, nearly arranged in rows and tiers. Many tubercles were assembled with a short pointed prickle in the centre. Microhairs were two-celled, panicoid type, with short basal cell and longer distal cell, $41-47 \mu \mathrm{m}$ long, located in the furrows. Papillae were rounded, numerous.

All members of the $O$. sativa group had simple tubercles, without prickles on the centre, positioned on the ridges. The tubercles were arranged in order and formed into rows and tiers. Microhairs and prickles located in furrows between tubercles. Microhairs were two-celled, panicoid type. Prickles were long, large and pointed. Papillae scattered.

O. sativa (Fig. 5c,d). Lemma and palea were 8.5 $9 \mathrm{~mm}$ long and 2.4-3 $\mathrm{mm}$ wide. Tubercles were $61-$ $77 \mu \mathrm{m}$ wide, with 2-4 sharp points, arranged on the ridges in orderly rows and tiers. Microhairs were twocelled, panicoid type, 40-52 $\mu \mathrm{m}$ in length, located in the furrows between tubercles, scattered. Prickles were one-celled, pointed, $245-310 \mu \mathrm{m}$ in length, in the furrows between tubercles, scattered. Papillae rounded, scattered.

O. rufipogon (Fig. 6a,b). Lemma and palea were $7-8 \mathrm{~mm}$ long and $2.2-2.5 \mathrm{~mm}$ wide. Tubercles were $51-57 \mu \mathrm{m}$ wide, with 3 or 4 sharp points, arranged on the ridges in orderly rows and tiers. Microhairs were two-celled, panicoid type, 34-40 $\mu \mathrm{m}$ length, located in the furrows between tubercles. Prickles were onecelled, pointed, $170-220 \mu \mathrm{m}$ in length, arranged in the furrows between tubercles, scattered. Papillae rounded, scattered.

O. officinalis (Fig. 6c,d). Lemma and palea were 4-5 $\mathrm{mm}$ long and 2-2.4 $\mathrm{mm}$ wide. Tubercles were $77-86 \mathrm{~mm}$ wide, with 2-4 sharp points, arranged on the ridges in orderly rows and tiers. Microhairs were two-celled, located in the furrows between tubercles. Prickles were one-celled, pointed, about $350 \mu \mathrm{m}$ in 

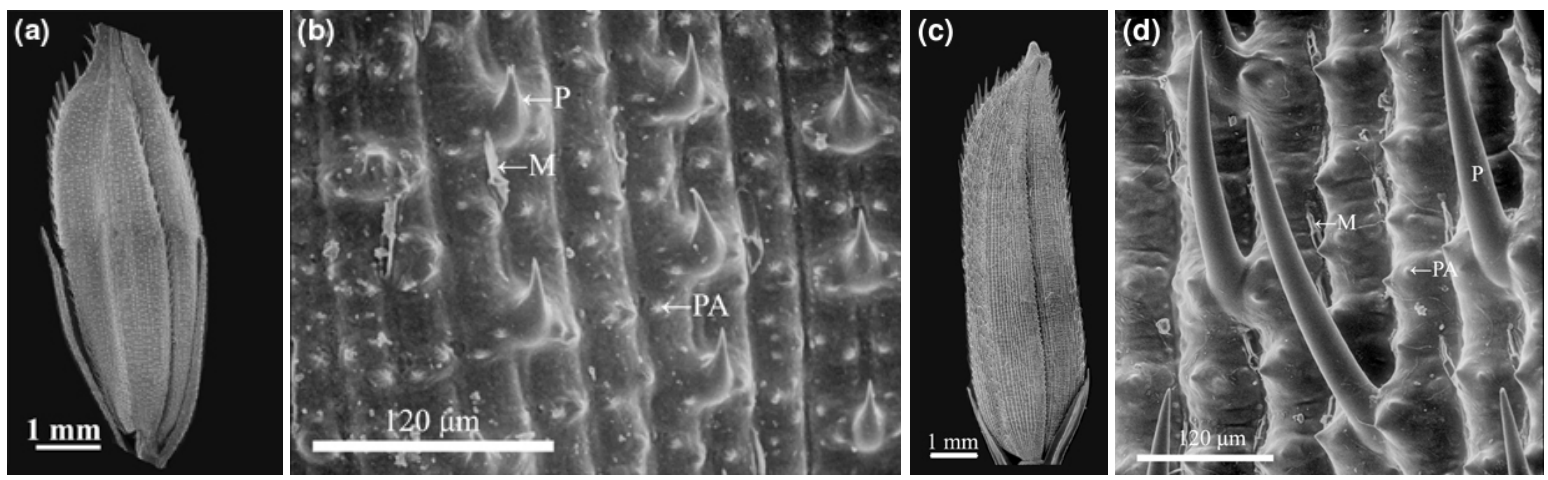

Fig. 5 SEM micrographs of the lemma of (a)-(b) O. ridleyi and (c)-(d) O. sativa $(\mathrm{P}=$ prickle; $\mathrm{M}=$ microhair; $\mathrm{PA}=$ papillae).
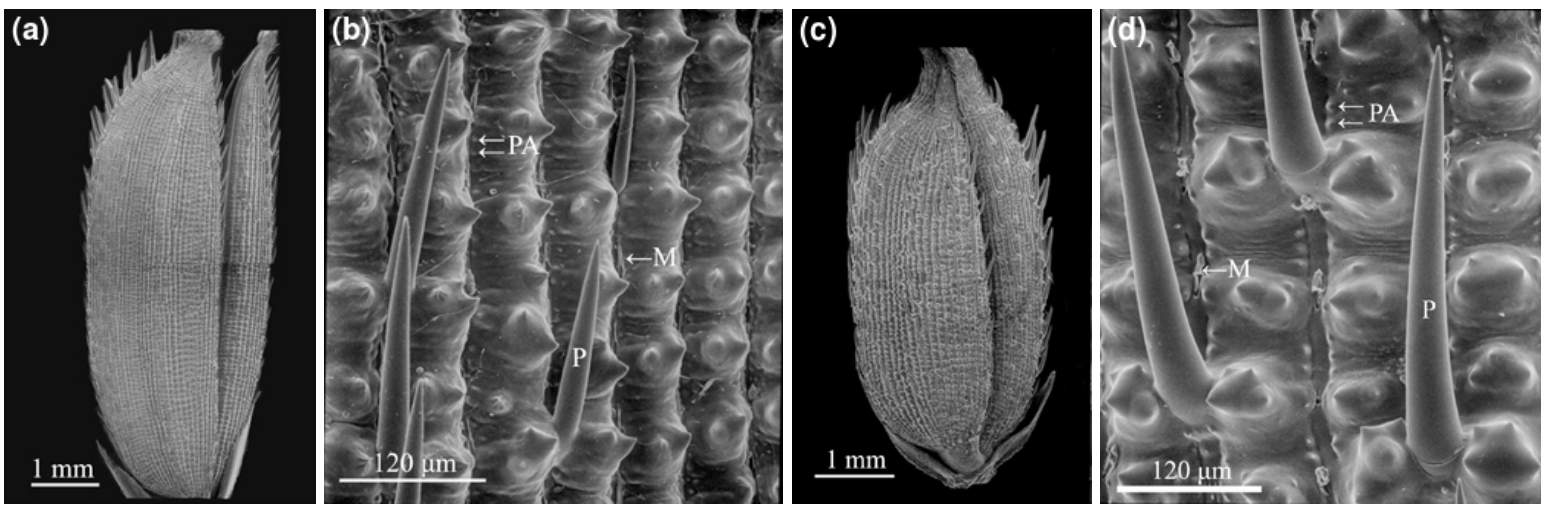

Fig. 6 SEM micrographs of the lemma of (a)-(b) O. rufipogon and (c)-(d) O. officinalis (P = prickle; $\mathrm{M}=$ microhairs; $\mathrm{PA}=$ papillae).

length, scattered over the surface of lemma. Papillae rounded, scattered.

These SEM observations revealed micromorphological characters of lemma surfaces which can be used to construct a key to species for Oryzeae in Thailand (Table 2). However, these characters are insufficient to separate the species of the $O$. sativa group (O. sativa, O. rufipogon, and O. officinalis).

\section{DISCUSSION}

Epidermal characters provide valuable information for classification and identification at the species and family levels, since these characters often exhibit highly specific forms that are unaffected by the environment ${ }^{11}$. In general, epidermal features of paleas are similar to those of lemmas ${ }^{20,21}$. The micromorphology of lemma corresponds to that of palea. The basic features on epidermal structures are microhairs, prickles, papillae, and silica bodies.

All Oryzeae species examined in this study contained bicellular microhairs (panicoid type: a short basal cell and a longer apical cell). Microhairs in most
Table 2 Identification key based on lemma surfaces.

1a. Silica bodies four-lobed $\ldots \ldots \ldots \ldots \ldots . . .$. aristata

1b. Silica bodies not as above ................. 2

2a. Silica bodies triads with

terminal pores $\ldots \ldots \ldots \ldots \ldots \ldots \ldots$. hexandra

2b. Silica bodies not as above $\ldots \ldots \ldots \ldots \ldots \ldots$

3a. Papillae of two types: rounded

and pitted $\ldots \ldots \ldots \ldots \ldots \ldots \ldots \ldots$. latifolia

3b. Papillae of one type: rounded $\ldots \ldots \ldots \ldots \ldots \ldots \ldots 4$

4a. Tubercles on the ridges, arranged in orderly rows and tiers .......... sativa group

$4 \mathrm{~b}$. Tubercles over the furrows $\ldots \ldots \ldots \ldots \ldots \ldots 5$

5a. Simple tubercles ................... O. ridleyi

5b. Complex tubercles .......................6 6

6a. Tubercles scattered densely $\ldots \ldots \ldots \ldots$ O. meyeriana var. granulata

6b. Tubercles scattered almost orderly ...... O. meyeriana var. meyeriana

of our materials were collapsed and broken off due to air-drying as part of the herbarium specimen preparation and SEM fixation process. Other researchers 
also faced this problem ${ }^{20,22}$. To solve this problem, fresh material should be used and prepared through chemical fixation and critical point drying.

Prickles are unicellular and sharp pointed, except in two varieties of $O$. meyeriana which have slightly bent prickles. Papillae are rounded, except in Z. latifolia which has two types of papillae (rounded and pitted). This observation of Z. latifolia corroborates the findings of Terrell and Wergin ${ }^{22}$. The pitted siliceous papillae are unique to $Z$. latifolia, readily distinguishing it from other Zizania species. Terrell and Wergin ${ }^{22}$ suggested that pits developed from the collapse of the top of papillae.

Silica bodies are valuable for identification of Oryzeae species. The four-lobed silica bodies and siliceous triads can separate $H$. aristata and L. hexan$d r a$ from the others, respectively. The siliceous triads consist of a silica body and two large tubercles with terminal pores on each side of silica body. This result agrees with a previous study of Leersia ${ }^{21}$.

Terrell et al ${ }^{20}$ supposed that tubercles are unique to genus Oryza. However, we found a different form of tubercle in L. hexandra. A phylogenetic tree based on chloroplast DNA fragment data showed a sister relationship between Oryza and Leersia in the subtribe Oryzinae $^{6}$, whereas Hygroryza and Zizania, which do not have tubercles, were included in the subtribe Zizaniinae. Tubercles might therefore be an important feature for the circumscription of taxa in this subtribe. Micromorphological studies of the remaining genera are required to confirm the value of this feature in distinguishing between the two subtribes.

Although L. hexandra has tubercles formed of triads with silica bodies, the tubercles of Oryza are more specialised, siliceous, 1- to 4- pronged structures. This structure is significant for identification and classification of the taxa in Oryza. Based on our findings, we can divide the six taxa of Oryzeae in Thailand into three groups: the $O$. sativa, $O$. ridleyi, and $O$. meyeriana groups, respectively. These are consistent with the groupings identified by Terrell et $\mathrm{al}^{20}$. However, we cannot separate the three species in the $O$. sativa group by using micromorphology of lemma surface alone. These three species have similar characters in terms of lemma surfaces, so other characters are needed to identify them. For instance, they can be distinguished by awn and spikelet size.

Furthermore, the surface patterns of cereal grains can be used in archaeobotanical studies, for instance in wheat and rye ${ }^{25}$. Rice is one of the crops that archaeologists were interested in its domestication ${ }^{26}$ and rice grains were found in many archaeological sites $^{26-28}$. Hence we can use lemma micromorpholog- ical information to identify species of plant remains which were collected from the sites.

In conclusion, the SEM study of lemma surfaces in Thai Oryzeae reveals several informative features, especially with respect to silica bodies, tubercles, and papillae useful for classification and identification. A key based on these characters clearly separates each taxon, except those of the $O$. sativa group, which require additional characters from other parts of the spikelet in combination with other morphological characters for accurate discrimination.

Acknowledgements: The authors are grateful to the reviewers for valuable comments to improve our manuscript. We give special thanks to the curators of the herbaria in Bangkok Herbarium (BK), the herbarium of Department of Biology, faculty of Science, Khon Kaen University, and Forest Herbarium (BKF) that provided plant materials to use in this study. In addition, we thank Dr S.W. Gale for critical reading on the manuscript. This project is supported by Mahidol University.

\section{REFERENCES}

1. Clayton WD, Renvoize SA (1986) Oryzeae. In: Clayton WD, Renvoize SA Genera Graminum: Grasses of the World, Kew Publishing, Royal Botanic Gardens, London, pp 70-5.

2. Weatherwax P (1929) The morphology of the spikelets of six genera of Oryzeae. Am J Bot 16, 547-55.

3. Sarwar AKMG, Ali MA (2002) Studies on the leaf epidermis of rice (Oryza sativa L.). Indian J Agr Res 36, 24-8.

4. Klush GS (1997) Origin, dispersal, cultivation and variation of rice. Plant Mol Biol 35, 25-34.

5. Ge S, Li A, Lu B, Zhang S, Hong D (2002) A phylogeny of the rice tribe Oryzeae (Poaceae) based on matK sequence data. Am J Bot 89, 1967-72.

6. Tang L, Zou X, Achoundong G, Potgieter C, Second G, Zhang D, Ge S (2010) Phylogeny and biogeography of the rice tribe (Oryzeae): Evidence from combined analysis of 20 chloroplast fragments. Mol Phylogenet Evol 54, 266-77.

7. Wu Z, Ge S (2012) The phylogeny of the BEP clade in grasses revisited: Evidence from the whole-genome sequences of chloroplasts. Mol Phylogenet Evol 62, 573-8.

8. Grass Phylogeny Working Group (2001) Phylogeny and subfamilial classification of the grasses (Poaceae). Ann Missouri Bot Gard 88, 373-457.

9. Kellogg EA (2009) The evolutionary history of Ehrhartoideae, Oryzeae, and Oryza. Rice 2, 1-14.

10. Na Nakorn W (1996) Gramineae (Poaceae) in Thailand, Queen Sirikit Botanic Garden, Chiang Mai.

11. Barthlott W (1981) Epidermal and seed surface characters of plants: systematic applicability and some evolutionary aspects. Nord J Bot 1, 345-55. 
12. Kantachot C, Chantaranothai P (2011) Achene morphology of Polygonum s.l. (Polygonaceae) in Thailand. Trop Nat Hist 11, 21-8.

13. Juan R, Pastor J, Fernández I (2000) SEM and light microscope observations on fruit and seeds in Scrophulariaceae from southwest Spain and their systematic significance. Ann Bot 86, 323-38.

14. Reimer E, Cota-Sánchez JH (2007) An SEM survey of the leaf epidermis in Danthonioid grasses (Poaceae: Danthonioideae). Syst Bot 32, 60-70.

15. Liu Q, Zhang DX, Peterson PM (2010) Lemma micromorphological characters in the Chloridoideae (Poaceae) optimized on a molecular phylogeny. $S$ Afr J Bot 76, 196-209.

16. Sánchez E, Montiel M, Espinoza AM (2003) Ultrastructural morphologic description of the wild rice species Oryza latifolia (Poaceae) in Costa Rica. Rev Biol Trop 51, 345-54.

17. Sánchez E, Espinoza AM (2005) Ultrastructure of Oryza glumaepatula, a wild rice species endemic of tropical America. Rev Biol Trop 53, 15-22.

18. Sánchez E, Quesada T, Espinoza AM (2006) Ultrastructure of the wild rice Oryza grandiglumis (Gramineae) in Costa Rica. Rev Biol Trop 54, 377-85.

19. Hoagland RE, Paul RN (1978) A comparative SEM study of red rice and several commercial rice (Oryza sativa) varieties. Weed Sci 26, 619-25.

20. Thammawongsa T, Sanitchon J, Meesawat A, Itharat P (2012) Morphological and anatomical characters of lowland-black rice grains in the northeast of Thailand. KKU Sci J 40, 1138-48.(in Thai).

21. Terrell EE, Peterson PM, Wergin WP (2001) Epidermal features and spikelet micromorphology in Oryza and related genera (Poaceae: Oryzeae). Smithsonian Contrib Bot 91, 1-50.

22. Terrell EE, Wergin WP, Renvoize SA (1983) Epidermal features of spikelets in Leersia (Poaceae). Bull Torrey Bot Club 110, 423-34.

23. Terrell EE, Wergin WP (1981) Epidermal features and silica deposition in lemmas and awns of Zizania (Gramineae). Am J Bot 68, 697-707.

24. Metcalfe CR (1960) Anatomy of the Monocotyledons. 1: Gramineae. Clarendon Press, Oxford.

25. Körber-Grohne U (1981) Distinguishing prehistoric cereal grains of Triticum and Secale on the basis of their surface patterns using the scanning electron microscope. J Archaeol Sci 8, 197-204.

26. Fuller DQ, Qin L, Zheng Y, Zhao Z, Chen X, Hosoya LA, Sun G (2009) The domestication process and domestication rate in rice: spikelet bases from the Lower Yangtze. Science 323, 1607-10.

27. Chen T, Wu Y, Zhang Y, Wang B, Hu Y, Wang C, Jiang $H$ (2012) Archaeobotanical study of ancient food and cereal remains at the Astana cemeteries, Xinjiang, China. PLoS ONE 7, e45137.

28. Jin GY, Wu WW, Zhang KS, Wang ZB, Wu XH (2013) 8000 -year old rice remains from the north edge of the
Shandong Highlands, East China. J Archaeol Sci (in press). 